\title{
Evolution of alarm cues: a role for kin selection? [version 1;
}

\section{peer review: 2 approved with reservations]}

\author{
Denis Meuthen, Sebastian A Baldauf, Timo Thünken
}

Institute for Evolutionary Biology and Ecology, University of Bonn, An der Immenburg, Bonn, D-53121, Germany

\author{
V1 First published: 11 Oct $2012,1: 27$ \\ https://doi.org/10.12688/f1000research.1-27.v1 \\ Latest published: 27 May 2014, 1:27 \\ https://doi.org/10.12688/f1000research.1-27.v2
}

\section{Open Peer Review}

\begin{tabular}{lcc} 
Approval Status & $? ?$ & 2 \\
& 1 & \\
\hdashline & & $?$ \\
version 2 & $?$ & $?$ \\
(revision) & view & view \\
27 May 2014 & $?$ & $?$ \\
version 1 & $?$ & view \\
11 Oct 2012 & view &
\end{tabular}

1. Dustin Rubenstein, Columbia University,

New York, NY, USA

2. Maurice W Sabelis, University of Amsterdam, Amsterdam, The Netherlands

Martijn Egas, University of Amsterdam, Amsterdam, The Netherlands

Paulien JA de Bruijn, University of

Amsterdam, Amsterdam, The Netherlands

Any reports and responses or comments on the article can be found at the end of the article. 
Corresponding author: Denis Meuthen (dmeuthen@evolution.uni-bonn.de)

Competing interests: No competing interests were disclosed.

Grant information: This research was funded by the Deutsche Forschungsgemeinschaft (TH 1615/1-1).

The funders had no role in study design, data collection and analysis, decision to publish, or preparation of the manuscript.

Copyright: ( 2012 Meuthen D et al. This is an open access article distributed under the terms of the Creative Commons Attribution

License, which permits unrestricted use, distribution, and reproduction in any medium, provided the original work is properly cited. Data associated with the article are available under the terms of the Creative Commons Zero "No rights reserved" data waiver (CC0 1.0 Public domain dedication).

How to cite this article: Meuthen D, Baldauf SA and Thünken T. Evolution of alarm cues: a role for kin selection? [version 1; peer review: 2 approved with reservations] F1000Research 2012, 1:27 https://doi.org/10.12688/f1000research.1-27.v1

First published: 11 Oct 2012, 1:27 https://doi.org/10.12688/f1000research.1-27.v1 


\section{Editorial note:}

Please note that the refereeing status of this article was changed from "indexed" to "[v1; ref status: approved with reservations 2]".

When this article was first published, F1000Research was still in its beta phase; during this period articles that received any two of "Approved" or "Approved with Reservations" statuses from the reviewers were labelled as "indexed". When the journal was formally launched in January 2013, the requirements for indexing were tightened, and only articles that are given either two "Approved" or one "Approved" plus two "Approved with Reservations" statuses by the reviewers are labelled "indexed". The new criteria for "indexing" can still be met in the future if a new revised version receives the necessary approval status from the reviewers.

\section{Introduction}

Alarm signals are signals that are emitted by individuals in the presence of predators. These signals may not only divert predator attention or discourage it to attack but also alert conspecifics ${ }^{1}$. Alarm signals can be transmitted via different communication pathways: alarm calls are widespread among social terrestrial animals (rodents ${ }^{2}$, birds $^{3}$ and primates ${ }^{4}$ ). Other animal species use alarm pheromones for the same purpose (insects ${ }^{5,6}$ or mice $^{7}$ ). In aquatic environments, chemical alarm signals are widespread especially due to the large number of water-soluble compounds ${ }^{8}$ (insects ${ }^{9}$, crustaceans $^{10}$, asteroids $^{11,12}$, gastropods ${ }^{13,14}$, amphibians ${ }^{15,16}$ and fishes ${ }^{17}$ ). Signaling is usually costly for the individual sender ${ }^{18}$ and often appears to primarily benefit the receivers. However, to evolve and be maintained by natural selection, the fitness benefits for the signaling individual must override its costs.

The evolution of alarm cues in fishes is a particularly puzzling example of alarm signaling whose evolution has intrigued evolutionary ecologists since the 1960 's ${ }^{19,20}$ until today $^{21}$. Alarm cues, also termed 'Schreckstoff" ${ }_{22,23}$ are located in specialized epidermal 'club cells ${ }^{24-26}$. They are released following injuries by predators, and widespread among different fish taxa including cichlids ${ }^{25,27}$. Signal-receiving conspecifics benefit because the presence of alarm cues reliably indicates high predation risk, thus allowing them to respond to predator presence in order to increase survival ${ }^{28,29}$. However, the benefits to the signaler are unclear because it often may not survive a predatory attack. Furthermore, alarm cue production is energetically demanding ${ }^{30}$.

Several hypotheses have been proposed to explain the phenomenon of alarm cues in fishes ${ }^{31,32}$. First, alarm cues might benefit the survival of the producing individual. In this context, it has been proposed that alarm pheromones may function to attract secondary predators ${ }^{33}$. During the following interference between competing predators prey might be able to escape. Mathis et al. showed that pike Esox lucius and predatory diving beetles were indeed attracted by minnow alarm cues ${ }^{33}$. In the presence of such secondary predators (pike), escape probabilities of minnows were actually increased $^{34}$. Accordingly, the signaling individual can increase its own fitness by producing alarm cues, provided that it survives an initial predator attack.

Other authors proposed that the alarm function is a mere by-product and instead suggested the primary function of alarm cues to be antipathogenic agents ${ }^{35}$ or promote the healing of injuries ${ }^{36}$. A recent study supported this hypothesis; club cell production was unrelated to predation risk but stimulated by skin penetrating pathogens and parasites $^{37}$. Moreover they found that UV radiation also affected club cell production, providing evidence for a general immune function of alarm cues.

A further hypothesis relying on Hamilton's inclusive fitness theory predicts that individuals can increase their fitness indirectly by supporting the survival of genetically related individuals ${ }^{38}$, coined 'kin selection' by Maynard-Smith ${ }^{39}$. Generally, costly communication is facilitated when interacting individuals are related ${ }^{40}$. While kin selection has been suggested to play an important role in the evolution of mammalian alarm calls ${ }^{2,41-43}$ (but see ${ }^{44}$ ), its significance for the evolution of alarm cues in fishes has received little attention ${ }^{30}$. Indirect benefits can be gained when kin particularly benefit from alarm cue production. This might be reached when individuals are able to discriminate between the alarm signals of different senders ${ }^{45}$. Higher sensitivity to kin-alarm cues may result in an improved response to predation, and thus higher survival of individuals related to the sender which in turn may increase the indirect fitness of the sender.

The aim of the present experiment was to test whether the cichlid fish Pelvicachromis taeniatus discriminates between alarm cues produced by kin and non-kin. P. taeniatus is a socially monogamous small cave-breeder with biparental brood care ${ }^{46}$ which inhabits streams in Western Africa ${ }^{47}$. Previous studies revealed that this species possesses alarm cues, recognizes conspecific alarm cues and adjusts its behavior in the presence of alarm cues (Meuthen et al., submitted, unpublished data). Furthermore, P. taeniatus is capable of kin recognition ${ }^{48-50}$ which is most likely based on chemical cues ${ }^{51-53}$. In the experiment we measured the change in activity in individual $P$. taeniatus after the addition of alarm cues derived from kin and non-kin, respectively.

\section{Material and methods}

\section{Ethics statement}

This study conforms to the Association for the Study of Animal Behaviour's Guidelines for the Use of Animals in Research and was carried out according to the German laws for experimentation with animals ( $\$ 8$ Abs. 1 TierSchG, V.m. $§ 2$ Abs. 1.1 TierSchZustV NW 26.9.1989). No additional licences were required.

\section{Animal collection and maintenance}

We conducted an experiment using female F2 progeny of the cichlid species Pelvicachromis taeniatus, whose ancestors (F0) were collected from the Moliwe river near Limbe, Cameroon (0404' N, $09^{\circ} 16^{\prime}$ E). Female $P$. taeniatus were used exclusively due to their consistent activity levels ${ }^{54}$. Prior to experiments, fish were kept in mixed-sex $50 \times 30 \times 30 \mathrm{~cm}(\mathrm{~L} \times \mathrm{W} \times \mathrm{H})$ stock tanks at densities up 
to 20 individuals and were fed daily with frozen invertebrate larvae ad libitum. These tanks were illuminated in a 12:12 h light:dark cycle; water temperature was kept at $25 \pm 1^{\circ} \mathrm{C}$.

\section{Experimental setup}

During experiments, we manipulated predation risk in three treatments by exposing individual fish to one of the following extracts: (1) Alarm cues derived from kin (from familiar and unfamiliar siblings); (2) Alarm cues derived from unfamiliar, unrelated conspecifics (non-kin); (3) Distilled water to control for disturbance effects upon introduction. We produced alarm cues from 26 donor cichlids which were previously starved for two days to exclude any effects caused by the individual's selective diet. Each alarm cue consisted of a male and a female cichlid to control for sex effects. Fish were anaesthetized with a blow to the head and afterwards euthanized by cervical dislocation in accordance to $\S 4$ of the German animal welfare act (BGB 1. I S. 1207, 1313). They were then placed into a mortar and grinded with a pestle. This procedure, imitating a lethal predation event, ruptured cells and thus allowed alarm pheromones to be released. The homogenate was diluted with distilled water, passed through filter floss and frozen in $1 \mathrm{ml}$ aliquots at $-20^{\circ} \mathrm{C}$ until use. The final concentration each fish was exposed to during trials was $3.6 \mathrm{mg} / \mathrm{l}$ donor wet fish weight. Likewise, we prepared $1 \mathrm{ml}$ aliquots of pure distilled water for control experiments.

Trials were run in $30 \times 20 \times 20 \mathrm{~cm}$ tanks which were supplemented with a $0.5 \times 0.5 \mathrm{~cm}$ grey plastic tube leading below the water level at the middle of their short side. This duct allowed the direct addition of chemical cues into the tanks while minimizing fish disturbance. Furthermore, experimental tanks were surrounded on all sides (except the top) with white polystyrene to prevent fish agitation by neighboring fish or the experimenter. A video camera (QuickCam 9000, Logitech, China) viewing the tanks from the top enabled recording of fish behavior for evaluation. Tanks were filled with substrate-treated water ${ }^{54}$; individual fish were then introduced and acclimatized for $1 \mathrm{~h}$, this period is referred to as the prestimulus phase from now on. Experimental stimuli were thereafter temperature-adjusted to tank conditions and introduced at the point of $1 \mathrm{~h} 15 \mathrm{~min}$. Subsequently, fish behavior was recorded for another hour. Afterwards, the experimental subjects were sized accurate to the nearest millimeter and weighed accurate to one milligram on an electrical precision scale (LC 2215, Sartorius, Germany). Between trials, tanks were cleaned with $3 \%$ hydrogen peroxide and then rinsed with tap water to remove remaining olfactory traces ${ }^{55,56}$. Furthermore, experimental stimuli assigned to individual tanks were alternated between trials.

In total, we tested 51 individuals from 8 families; extracts from the same donor fish were used throughout different treatments and thus represented - based on the family identity of the focal fish as either related or unrelated conspecifics. Also, individuals from the same family were evenly distributed among the three extracts. Because in two cases the fish exhibited no activity during the prestimulus phase, we excluded them from analysis. Hence, the final sample size consisted of 49 individuals; 12 received alarm cues from familiar siblings, 9 from unfamiliar siblings, 14 from unrelated fish and 14 individuals were exposed to the control stimulus. Because sibling familiarity did not significantly affect focal fish activity (familiar $v s$. unfamiliar kin: $\chi^{2}=0.090, \mathrm{p}=0.764$ ), their activity scores were pooled to represent 21 fish receiving alarm cues derived from kin.

\section{Statistical analysis}

We evaluated fish activity by tracking its movement during $1 \mathrm{~h}$ prestimulus phase and the following $1 \mathrm{~h}$ post-stimulus phase with animal tracking software (Biobserve Viewer ${ }^{2}$, St. Augustin, Germany). Subsequently, we assigned an activity index to each fish by calculating the difference between the distances covered during the two experimental phases. Activity indices did not deviate significantly from normal distribution according to the Kolmogorov-Smirnov test (Lillie.test, R library "nortest"), thus we applied linear-mixed effect models (LME, R library "nlme") for analysis. All test fish were only used once but to account for the repeated use families, we entered "family identity" as a random factor. All results were based on likelihood ratio tests (LRT); hence degrees of freedom always differed by one.

\section{Results}

The change in activity of female $P$. taeniatus was significantly affected by the treatment $\left(\chi^{2}=10.057, p=0.007\right.$, Figure 1$)$. Activity indices of both alarm-cue treatment groups (kin/non-kin) were significantly different from those of the water-control group (Kin vs. water: $\chi^{2}=8.346, \mathrm{p}=0.004$; Non-kin vs. water: $\chi^{2}=8.693$, $\mathrm{p}=0.003$, Figure 1). Whereas fish of the control group showed on average an increase of $0.67 \mathrm{~m}$ in covered distance during the post-stimulus period, fish of both alarm cue treatments showed reduced activity in the post-stimulus phase (on average $0.31 \mathrm{~m}$ less

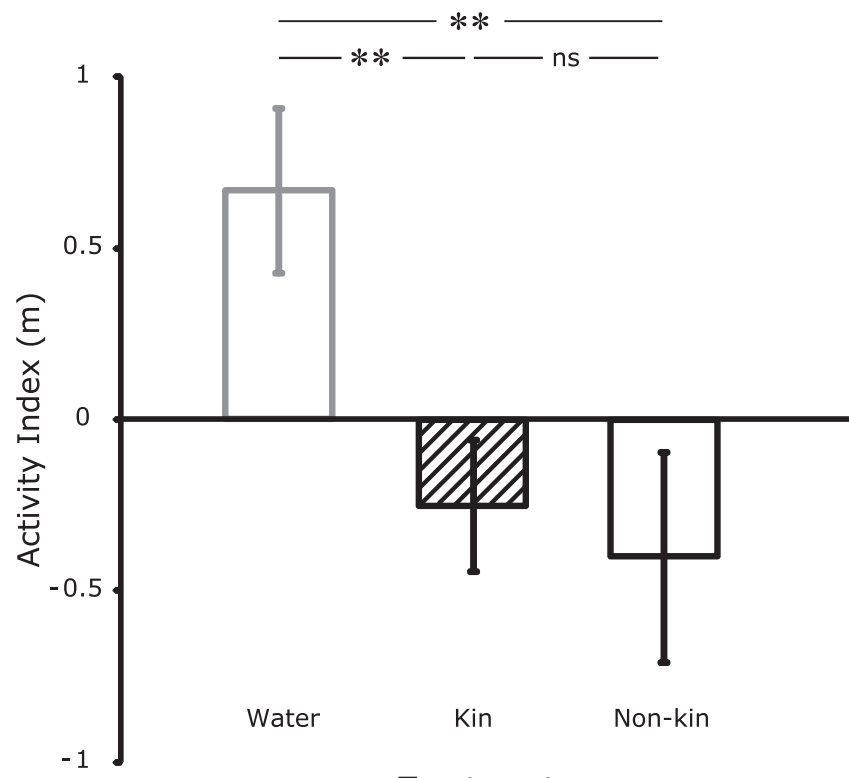

Treatment

Figure 1. Activity indices of female $P$. taeniatus (mean \pm SD) exposed to distilled water (gray open bar) and alarm cues derived from related conspecifics (kin, black hatched bar) or unrelated conspecifics (non-kin, black open bar). Activity indices were calculated by subtracting the distance covered during the $1 \mathrm{~h}$ prestimulus phase from the following $1 \mathrm{~h}$ poststimulus period. Asterisks above the bars indicate ${ }^{* *} p<0.01 ; n s p>0.6$. 
compared to the pre-stimulus phase). However, fish did not respond differentially to alarm cues derived from related and unrelated individuals $\left(\chi^{2}=0.233, \mathrm{p}=0.630\right)$.

\section{Fish activity data}

1 Data File

http://dx.doi.org/10.6084/m9.figshare.96320

\section{Discussion}

Generally, activity of female $P$. taeniatus was affected by the presence of conspecific alarm cues. Fish of the alarm cue treatment significantly decreased their activity relative to control fish. However, $P$. taeniatus did not discriminate between alarm cues derived from kin or non-kin in terms of activity changes.

These results are in accordance to numerous studies showing that the presence of conspecific alarm cues decreases prey activity in general $^{57,58}$. Reduced activity concurrently decreases prey conspicuousness, which is an effective strategy against visual predators and enhances prey survival ${ }^{58}$. Furthermore, our results add to an earlier study, showing that males of $P$. taeniatus reduce territorial aggression in the presence of conspecific alarm cues (Meuthen et al., submitted, unpublished data). Thus both sexes of $P$. taeniatus are capable of recognizing alarm cues and adjust their behavior accordingly.

Against the expectations of the kin selection hypothesis, fish did not discriminate between kin and non-kin alarm cues. This is also surprising because theoretical models proposed that the evolution of communication in general is driven by the interaction between siblings ${ }^{40}$ and kin selection has been suggested to play an important role in the evolution of different alarm signals such as alarm calls $^{2,41-43}$ but see $^{44}$. Furthermore, individual discrimination of alarm signals is predicted to be highly beneficial ${ }^{45}$. However, lack of discrimination does not necessarily mean lack of recognition ${ }^{59}$. Thus, further studies in different contexts are required to confirm the present results. The results are in accordance with the "direct benefits" hypotheses ${ }^{32}$, including those hypotheses highlighting that alarm cues have primarily evolved as an immune enhancing mechanism and that the alarm signaling function is a by-product ${ }^{37}$. They are also in accordance with the theory that chemical signals have originally evolved from compounds without a communicative function ${ }^{8}$.

On a molecular level, the missing discrimination may result from a lack of kin-related information within alarm cues. Although to date, some studies were able to identify single chemical components of alarm cues such as Hypoxanthine-3-N-oxide ${ }^{60,61}$ or the glycosaminoglycan chondroitin ${ }^{62}$, the full suite of alarm cue components still remains to be identified ${ }^{62}$. The results of behavioral experiments have suggested that substantial individual variation in alarm cues exists. Sender body condition was determined to be an important factor affecting alarm cue response ${ }^{63}$. These results were, however, attributed to differences in club cell quantity ${ }^{30}$ because fish display graded responses based on alarm cue concentration ${ }^{64}$. Unidentified qualitative effects could, however, also be responsible for the altered response, especially because not all behaviors were specific to sender condition - whereas changes in activity and shoaling density were specific to sender condition, aggression remained unaffected ${ }^{65}$.

Kin discrimination in alarm cues might simply not have evolved in $P$. taeniatus due to the lack of necessity. The increase in fitness due to kin discrimination in alarm cues might not be sufficient to cause the necessary impact on natural selection, causing kin-related information to evolve in alarm cues. Many fishes are capable of identifying kin and live in kin-shaped groups ${ }^{66}$. This is also true for $P$. taeniatus which lives the first weeks of hatching in family group guarded by their parents ${ }^{46}$. Afterwards they live in shoals without defined territories throughout the juvenile stage ${ }^{47}$. Laboratory experiments showed that they prefer to shoal with familiar kin (Thünken et al., unpublished data). Furthermore, P. taeniatus preferentially mate with kin $^{47}$ which is most likely also true for the natural population ${ }^{67}$. Accordingly, throughout their life the social environment of $P$. taeniatus is probably largely kin-structured in nature. In this case, individuals receiving the information transmitted by alarm cues are most likely kin. As a consequence, signaling individuals may increase their inclusive fitness.

In conclusion, our study found no evidence for differential response to kin derived alarm cues. However, under natural conditions behavioral mechanisms may lead to kin-biased alarm cue perception. Thus, kin selection potentially plays a role in alarm signaling in our model system. Still, further research is required determining the direct fitness benefits and costs for the signaling individual as well as the benefits for the receivers which are fundamental parameters to understand the evolution and maintenance of alarm cues.

\section{Author contributions}

TT and DM conceived the study. DM, SAB and TT designed the experiments. DM carried out the research. DM, SAB and TT analysed the data. DM and TT wrote the paper. All authors had read and improved the manuscript and agreed to the final content.

\section{Competing interests}

No competing interests were disclosed.

\section{Grant information}

This research was funded by the Deutsche Forschungsgemeinschaft (TH 1615/1-1).

The funders had no role in study design, data collection and analysis, decision to publish, or preparation of the manuscript.

\section{Acknowledgements}

We are grateful to the Bakker research group for discussion. 
1. Smith RJF: Evolution of alarm signals: Role of benefits of retaining group members or territorial neighbors. Am Nat. 1986; 128(4): 604-610. Reference Source

2. Sherman PW: Nepotism and the evolution of alarm calls. Science. 1977; 197(4310): 1246-1253.

PubMed Abstract | Publisher Full Tex

3. Klump GM, Shalter MD: Acoustic behavior of birds and mammals in the predator context. 1. Factors affecting the structure of alarm signals. 2. The functional significance and evolution of alarm signals. Z Tierpsychol. 1984; 66(3): 189-226.

Publisher Full Text

4. Macedonia JM, Evans CS: Essay on Contemporary Issues in Ethology: Variation among mammalian alarm call systems and the problem of meaning in animal signals. Ethology. 1993; 93(3): 177-197.

Publisher Full Tex

5. Blum MS: Alarm pheromones. Annu Rev Entomol. 1969; 14: 57-80. Publisher Full Tex

6. Kunert G, Otto $S$, Rose USR, et al: Alarm pheromone mediates production of winged dispersal morphs in aphids. Ecol Lett. 2005; 8: 596-603. Publisher Full Text

7. Rottman SJ, Snowdon CT: Demonstration and analysis of an alarm pheromone in mice. J Comp Physiol Psychol. 1972; 81(3): 483-490. PubMed Abstract | Publisher Full Tex

8. Steiger S, Schmitt T, Schaefer HM, et al.: The origin and dynamic evolution of chemical information transfer. Proc Biol Sci. 2011; 278(1708): 970-979. PubMed Abstract | Publisher Full Text | Free Full Text

9. Sih A: Antipredator responses and the perception of danger by mosquito larvae. Ecology. 1986; 67(2): 434-441. Publisher Full Text

10. Laforsch C, Beccara L, Tollrian R, et al:: Inducible defenses: The relevance of chemical alarm cues in Daphnia. Limnol Oceanogr. 2006; 51(3): 1466-1472. Publisher Full Text

11. Parker DA, Shulman MJ: Avoiding predation: Alarm responses of Caribbean sea-urchins to simulated predation on conspecific and heterospecific seaurchins. Mar Biol. 1986; 93(2): 201-208. Publisher Full Text

12. Lawrence JM: A chemical alarm response in Pycnopodia helianthoides (Echinodermata: Asteroidea). Mar Behav Physiol. 1991; 19(1): 39-44. Publisher Full Text

13. Sleeper HL, Paul VJ, Fenical W, et al.: Alarm pheromones from the marine opisthobranch Navanax inermis. J Chem Ecol. 1980; 6(1): 57-70. Publisher Full Text

14. Kempendorff W: Über das Fluchtphänomen und die Chemoreception von Helisoma (Taphius) nigricans. Arch Molluskenkd. 1942.

15. Hews DK, Blaustein AR: An investigation of the alarm response in Bufo boreas and Rana cascadae tadpoles. Behav Neural Biol. 1985; 43(1): 47-57. PubMed Abstract | Publisher Full Text

16. Kats LB, Petranka JW, Sih A, et al.: Antipredator defenses and the persistence of amphibian larvae with fishes. Ecology. 1988; 69(6): 1865-1870. Publisher Full Text

17. Wisenden $\mathrm{BD}$ : Olfactory assessment of predation risk in the aquatic environment. Philos Trans R Soc Lond B Biol Sci. 2000; 355(1401): 1205-1208. PubMed Abstract | Publisher Full Text | Free Full Text

18. Hughes AL: Evolution of adaptive phenotypic traits without positive Darwinian selection. Heredity (Edinb). 2012; 108(4): 347-353. PubMed Abstract | Publisher Full Text | Free Full Text

19. Williams GC: Measurement of consociation among fishes and comments on the evolution of schooling. Publications of the Museum, Michigan State University Biological Series. 1964; 2: 349-384. Reference Source

20. Williams GC: Natural selection: domains, levels, and challenges. (Oxford University Press, 1992) Reference Source

21. Chivers DP, Brown GE, Ferrari MCO, et al:: Chemical ecology in aquatic systems. eds C. Brönmark \& L. A. Hansson (Oxford University Press) 2012; 312. Reference Source

22. von Frisch K: Zur Psychologie des Fisch-Schwarmes. Naturwissenschaften 1938; 26(37): 601-606.

Publisher Full Text

23. von Frisch K: Über einen Schreckstoff der Fischhaut und seine biologische Bedeutung. Z Vgl Physiol. 1942; 29(1-2): 46-145 Publisher Full Text

24. Barreto RE, Barbosa A, Giassi ACC, et al:: The 'club' cell and behavioural and physiological responses to chemical alarm cues in the Nile tilapia. Mar Freshw Behav Physiol. 2010; 43(1): 75-81.

Publisher Full Text

25. Pfeiffer W: The distribution of fright reaction and alarm substance cells in fishes. Copeia. 1977; 1977(4): 653-665.

Reference Source

26. Kristensen EA, Closs GP: Anti-predator response of naive and experienced common bully to chemical alarm cues. J Fish Biol. 2004; 64(3): 643-652. Publisher Full Text

27. Mathis A, Perriere C, Zaccone G, et al:: In Fish defenses Volume 2: Pathogens, parasites and predators. eds G. Zaccone, C. Perriére, A. Mathis, \& B. G. Kapoor 2009; 2: 323-386 (Science Publishers)

Reference Source

28. Mathis A, Smith RJF: Chemical alarm signals increase the survival time of fathead minnows (Pimephales promelas) during encounters with northern pike (Esox lucius). Behav Ecol. 1993; 4(3): 260-265. Publisher Full Text

29. Stabell OB, Lwin MS: Predator-induced phenotypic changes in crucian carp are caused by chemical signals from conspecifics. Environ Biol Fishes. 1997; 49(1): $139-144$

Publisher Full Text

30. Wisenden BD, Smith RJF: The effect of physical condition and shoalmate familiarity on proliferation of alarm substance cells in the epidermis of fathead minnows. J Fish Biol. 1997; 50(4): 799-808.

Publisher Full Text

31. Chivers DP, Smith RJF: Chemical alarm signalling in aquatic predatorprey systems: A review and prospectus (fait parti du numéro thématique sur l'écologie chimique/part of the special feature on chemical ecology). Ecoscience. 1998; 5(3): 338-352. Reference Source

32. Smith RJF: Alarm signals in fishes. Rev Fish Biol Fish. 1992; 2(1): 33-63. Publisher Full Text

33. Mathis A, Chivers DP, Smith RJF, et al:: Chemical alarm signals: Predator deterrents or predator attractants? Am Nat. 1995; 145(6): 994-1005. Publisher Full Text

34. Chivers DP, Brown GE, Smith RJF, et al:: The evolution of chemical alarm signals: Attracting predators benefits alarm signal senders. Am Nat. 1996; 148(4): 649-659.

Publisher Full Text

35. Cameron AM, Endean R: Epidermal secretions and the evolution of venom glands in fishes. Toxicon. 1973; 11(5): 401-410. PubMed Abstract

36. Al-Hassan JM, Thompson M, Criddle RS, et al.: Composition of the proteinacous gel secretion from the skin of the Arabian Gulf catfish (Arius thallasinus). Mar Biol. 1982; 70(1): 27-33. Publisher Full Text

37. Chivers DP, Wisenden BD, Hindman CJ, et al: Epidermal 'alarm substance' cells of fishes maintained by non-alarm functions: possible defence against pathogens, parasites and UVB radiation. Proc Biol Sci. 2007; 274(1625): 2611-2619.

PubMed Abstract | Publisher Full Text | Free Full Text

38. Hamilton WD: The genetical evolution of social behaviour I. J Theor Biol. 1964 7(1): 1-16.

PubMed Abstract | Publisher Full Tex

39. Maynard-Smith J: Group selection and kin selection. Nature. 1964; 201(4924): 1145-1147. Publisher Full Text

40. Tamura K, Ihara Y: Classes of communication and the conditions for their evolution. Theor Popul Biol. 2011; 79(4): 174-183.

PubMed Abstract | Publisher Full Text

41. Charnov EL, Krebs JR: The evolution of alarm calls: Altruism or manipulation? Am Nat. 1975; 109(965): 102-107. Publisher Full Text

42. Sherman PW: Alarm calls of Belding's ground squirrels to aerial predators: nepotism or self-preservation. Behav Ecol Sociobiol. 1985; 17(4): 313-323. Publisher Full Text

43. da Silva KB, Mahan C, da Silva J, et al: The trill of the chase: Eastern chipmunks call to warn kin. $J$ Mammal. 2002; 83(2): 546-552. Publisher Full Text

44. Shelley EL, Blumstein DT: The evolution of vocal alarm communication in rodents. Behav Ecol. 2005; 16(1): 169-177.

Publisher Full Text

45. Pollard KA: Making the most of alarm signals: the adaptive value of individua discrimination in an alarm context. Behav Ecol. 2010; 22(1): 93-100. Publisher Full Text

46. Thünken T, Meuthen D, Bakker TCM, et al:: Parental investment in relation to offspring quality in the biparental cichlid fish Pelvicachromis taeniatus. Anim Behav. 2010; 80(1): 69-74.

Publisher Full Text

47. Lamboj A: Die Cichliden des westlichen Afrikas. (Birgit Schmettkamp Verlag)

Reference Source 
48. Thünken T, Bakker TC, Baldauf SA, et al:: Active inbreeding in a cichlid fish and its adaptive significance. Curr Biol. 2007; 17(3): 225-229.

PubMed Abstract | Publisher Full Text

49. Thünken T, Bakker TCM, Baldauf SA, et al:: Direct familiarity does not alter mating preference for sisters in male Pelvicachromis taeniatus (Cichlidae). Ethology. 2007; 113(11): 1107-1112.

Publisher Full Text

50. Thünken T, Meuthen D, Bakker TC, et al:: A sex-specific trade-off between mating preferences for genetic compatibility and body size in a cichlid fish with mutual mate choice. Proc Biol Sci. 2012; 279(1740): 2959-2964. PubMed Abstract | Publisher Full Text | Free Full Text

51. Thünken T, Waltschyk N, Bakker TC, et al.: Olfactory self-recognition in a cichlid fish. Anim Cogn. 2009; 12(5): 717-724.

PubMed Abstract | Publisher Full Text

52. Thünken $\mathrm{T}$, Baldauf $\mathrm{SA}$, Kullmann $\mathrm{H}$, et al:: Size-related inbreeding preference and competitiveness in male Pelvicachromis taeniatus (Cichlidae). Behav Ecol. 2011; 22(2): 358-362 Publisher Full Text

53. Hesse S, Bakker TCM, Baldauf SA, et al.: Kin recognition by phenotype matching is family-rather than self-referential in juvenile cichlid fish. Anim Behav. 2012; 84(2): 451-457. Publisher Full Text

54. Meuthen D, Baldauf SA, Bakker TCM, et al:: Substrate-treated water: a method to enhance fish activity in laboratory experiments. Aquat Biol. 2011; 13(1): 35-40. Publisher Full Text

55. McLennan DA: Male brook sticklebacks' (Culaea inconstans) response to olfactory cues. Behaviour. 2004; 141(11): 1411-1424.

Publisher Full Text

56. Mehlis M, Bakker TC, Frommen JG, et al:: Smells like sib spirit: kin recognition in three-spined sticklebacks (Gasterosteus aculeatus) is mediated by olfactory cues. Anim Cogn. 2008; 11(4): 643-650. PubMed Abstract | Publisher Full Text

57. Bourdeau PE, Johansson F: Predator-induced morphological defences as by-products of prey behaviour: a review and prospectus. Oikos. 2012; 121(8): $1175-1190$

Publisher Full Text
58. Kats LB, Dill LM: The scent of death: Chemosensory assessment of predation risk by prey animals. Ecoscience. 1998; 5(3): 361-394.

Reference Source

59. Mateo JM: Recognition systems and biological organization: The perception component of social recognition. Ann Zool Fenn. 2004; 41(6): 729-745. Reference Source

60. Brown GE, Adrian JC, Smyth E, et al:: Ostariophysan alarm pheromones: Laboratory and field tests of the functional significance of nitrogen oxides. $J$ Chem Ecol. 2000; 26(1): 139-154. Publisher Full Text

61. Pfeiffer W, Riegelbauer G, Meier G, et al:: Effect of hypoxanthine-3(N)-oxide and hypoxanthine-1(N)-oxide on central nervous excitation of the black tetra Gymnocorymbus ternetzi (Characidae, Ostariophysi, Pisces) indicated by dorsal light response. J Chem Ecol. 1985; 11(4): 507-523. Publisher Full Text

62. Mathuru AS, Kibat C, Cheong WF, et al:: Chondroitin fragments are odorants that trigger fear behavior in fish. Curr Biol. 2012; 22(6): 538-544. PubMed Abstract | Publisher Full Text

63. Roh E, Mirza RS, Brown GE, et al:: Quality or quantity? The role of donor condition in the production of chemical alarm cues in juvenile convict cichlids. Behaviour. 2004; 141(10): 1235-1248. Publisher Full Text

64. Brown GE, Bongiorno T, DiCapua DM, et al:: Effects of group size on the threatsensitive response to varying concentrations of chemical alarm cues by juvenile convict cichlids. Can J Zool. 2006; 84(1): 1-8. Publisher Full Text

65. Brown GE, Foam PE, Cowell HE, et al:: Production of chemical alarm cues in convict cichlids: the effects of diet, body condition and ontogeny. Ann Zool Fenn. 2004; 41(3): 487-499. Reference Source

66. Ward AJW, Hart PJB: The effects of kin and familiarity on interactions between fish. Fish and Fisheries. 2003; 4(4): 348-358. Publisher Full Text

67. Langen $\mathrm{K}$, Schwarzer J, Kullmann $\mathrm{H}$, et al:: Microsatellite support for active inbreeding in a cichlid fish. PLoS One. 2011; 6(9): e24689. PubMed Abstract | Publisher Full Text | Free Full Text 


\title{
Open Peer Review
}

\section{Current Peer Review Status: ? ?}

\section{Version 1}

Reviewer Report 02 November 2012

https://doi.org/10.5256/f1000research.150.r336

(c) 2012 Sabelis $\mathbf{M}$ et al. This is an open access peer review report distributed under the terms of the Creative Commons Attribution License, which permits unrestricted use, distribution, and reproduction in any medium, provided the original work is properly cited.

\begin{abstract}
Maurice W Sabelis
Institute for Biodiversity and Ecosystem Dynamics (IBED), University of Amsterdam, Amsterdam, The Netherlands

\section{Paulien JA de Bruijn}

Institute for Biodiversity and Ecosystem Dynamics (IBED), University of Amsterdam, Amsterdam, The Netherlands

\section{Martijn Egas}

Institute for Biodiversity and Ecosystem Dynamics (IBED), University of Amsterdam, Amsterdam, The Netherlands

Meuthen et al. describe the results of experiments to test whether the cichlid fish Pelvicachromis taeniatus discriminates between alarm cues produced by kin and non-kin upon being injured by a predator.
\end{abstract}

They manipulated alarm cues (as a proxy of predation risk) in three treatments by exposing individual fish to one of the following: (1) Alarm cues derived from kin (from familiar and unfamiliar siblings); (2) Alarm cues derived from unfamiliar, unrelated conspecifics (non-kin); (3) Distilled water to control for disturbance effects upon introduction. They showed that activity of fish receiving alarm cues from treatment 1 and 2 was reduced compared to the control (treatment 3), but familiarity of siblings (treatment 1 ) and kinship (treatment 1 vs 2) had no effect on activity. Meuthen et al. conclude that $P$. taeniatus fish do not discriminate between alarm cues from kin and non-kin. Finally, they argue that kin selection can only play a role if this fish usually lives in groups of kin and that alarm cues are more likely to have evolved as a by-product of wound-healing or immune responses to pathogens colonizing cells wounded by predators.

While their experiments are clearly described and carefully designed, we question whether the question in the title of the paper by Meuthen et al. is well posed: Evolution of alarm cues: a role for kin selection? First, alarm cues represent public information and we see no reason why kin and nonkin should respond differently to these cues (except in the very special case where predation risk differs between kin and non-kin). Hence, we disagree where the authors state: “Higher sensitivity to kin-alarm cues may result in an improved response to predation, and thus higher survival of 
individuals related to the sender which in turn may increase the indirect fitness of the sender". Why would a higher sensitivity to kin alarm be expected in the first place? Second, the experiments by Meuthen et al. were designed such that they exclude the possibility for wounded fish to decide on what and how much to send depending on whether it is surrounded by kin or non-kin. This presupposes that the wounded fish has some form of control over the amount of alarm cues that are released. In our view this extent of this sender control is an essential target for kin selection. Thus, to answer the question posed in the title of the paper the experiments should have been designed so as to allow the potential sender to perceive who are the potential receivers and so as to measure the amount of alarm cues released depending on their environment.

\section{Side remarks:}

(1) In the Materials and Methods section the authors state: "(experimental stimuli) ... were introduced at the point of $1 \mathrm{~h} 15 \mathrm{~min}$ and then fish behavior was recorded for another hour. Thereafter, all experimental subjects were sized accurate to the nearest millimeter and weighed accurate to one milligram on an electrical precision scale (LC 2215, Sartorius, Germany)". However, the results of these measurements are not described in the paper.

(2) In the Results section the analysis focuses on activity as the difference in distance covered by the fish before and after application of the treatment. These values may differ (as they do between treatments 1 and 2 vs 3 ) due to differences before treatment, but the authors seem to assume that any difference in this activity parameter is due to differences after application of the treatment. We strongly suggest the authors to provide a statistical test to show that the distances before treatment were not significantly different among the three groups.

Competing Interests: No competing interests were disclosed.

\section{We confirm that we have read this submission and believe that we have an appropriate level of expertise to confirm that it is of an acceptable scientific standard, however we have significant reservations, as outlined above.}

Author Response 27 May 2014

Denis Meuthen, University of Bonn, An der Immenburg, Bonn, Germany

Sabelis et al. critically remarked "whether the question in the title of the paper is well posed". To our opinion the evolution of alarm cues is puzzling as their production is a costly process (individuals with higher condition produce more alarm cues). If individuals benefit from alarm cues while not contributing to the alarm system by producing own alarm cues, they would increase in number and ultimately eliminate this alarm signaling system from evolution. Kin-biased perception could solve this problem. In accordance with this hypothesis a recent paper shows that discrimination between kin and non-kin volatile chemical (alarm) cues occurs in plants (Karban et al. 2013). Moreover, several studies suggest that familiarity with alarm signals (O'Connell-Rodwell et al. 2007) or chemical cues ( Coopersmith \& Leon 1984, Brown \& Smith 1994) leads to improved responses. Along the hypotheses of other researchers concerning the role of kin selection in the evolution of mammalian alarm calls (Sherman 1977, Charnov \& Krebs 1975, Sherman 1985, da Silva et al. 2002) and alarm cues of fishes (Smith 1992), we therefore expect that individual fish should respond differently to alarm cues derived from kin and non-kin. 
Furthermore, Sabelis et al. suggest that "wounded fish have some form of control over the amount of alarm cues that are released, ultimately providing an essential target for kin selection ". If wounded fish had the control, this would be indeed a possibility. However, it is usually assumed that alarm cues are passively released. Alarm cues are putatively located in enclosed subepidermal club cells without external ducts, thus providing little opportunity for short-term variation in the released alarm cue amount. Accordingly, the only way for alarm cues to be released is the destruction of these cells by predators. Therefore, we focused on the receiver part, i.e. whether individuals are differentially sensitive towards kin and non kin alarm cues. One possible control by the sender might be differential long-term investment in club cell quantity depending on whether the sender is surrounded by relatives. In the present study all fish grew up in kin groups prior to trials, therefore, we exclude the possibility of differential investment based on the long-term sender environment.

Following Sabelis et al. side remarks we included additional analyses regarding fish sizes and activities before the treatment. These analyses showed that neither fish size nor weight nor prestimulus activity differed significantly among the three treatment groups.

Competing Interests: No competing interests were disclosed.

Reviewer Report 15 October 2012

https://doi.org/10.5256/f1000research.150.r335

(C) 2012 Rubenstein D. This is an open access peer review report distributed under the terms of the Creative Commons Attribution License, which permits unrestricted use, distribution, and reproduction in any medium, provided the original work is properly cited.

\section{Dustin Rubenstein}

Department of Ecology, Evolution and Environmental Biology, Columbia University, New York, NY, USA

The premise of this study is based on a theoretical model (Pollard 2010, Behavioral Ecology) demonstrating that receivers might use signaler identity to infer signaler reliability.

Such a framework may be appropriate when different signalers vary in their reliability, but in the case of alarm cues released from dead or wounded fish, the likelihood of dishonest alarm signals seem low. In other words, it is not clear why one would expect different responses to kin or non-kin alarm cues in these cichlid fish. Given that these cues must always honestly signal the presence of predator because of how they are released when an individual is wounded, fish would be expected to respond to any cue they find in the water. I therefore wonder if in this type of system that kin selection hypothesis is even appropriate to test. It is therefore not surprising to me that the authors find no difference in response to kin or non-kin alarm cues. I would have liked to have seen more discussion about the appropriateness of testing this model in this type of signal-receiver system. 
Competing Interests: No competing interests were disclosed.

I confirm that I have read this submission and believe that I have an appropriate level of
expertise to confirm that it is of an acceptable scientific standard, however I have
significant reservations, as outlined above.

Author Response 27 May 2014

Denis Meuthen, University of Bonn, An der Immenburg, Bonn, Germany

Rubenstein criticized the reference to the theoretical model by Pollard 2010. We realized that the reference to the Pollard paper was a bit misleading and may have caused confusion. In our revision, we replaced this aspect with a more detailed explanation of why we expect kin selection to play a role in the evolution of alarm cues. We now include other studies previously highlighting the potential role of kin selection in the evolution of alarm signals, including fish alarm cues. A particularly interesting example on plants shows that sagebrush induces strong anti-herbivore protection mechanisms when exposed to the volatile (alarm) cues of wounded close relative plants. In contrast, the anti-herbivore response was weaker when they were exposed to volatiles from distantly related plants.

Second, Rubenstein raised concerns that due to physiological restrictions of alarm cues in fish, dishonest alarm signals are unlikely. We fully agree with the referee. However, it was not our intent to convey that our study is based on the premise of the dishonest or honest alarm signals which are referenced by Pollard 2010. Instead, we focus on the question whether kin are able to respond more quickly towards a predator by being more sensitive towards kin alarm cues. For this purpose, in our revision we present an argument outlining that the recognition of kin alarm cues could be based on an indirect coupling of concurrently present kin-specific cues and alarm cues. Accordingly, fish could be able to discriminate between kin- and non-kin alarm cues based on learned kin recognition. This would not be surprising as kin recognition has been shown to be present in fishes and injuries caused by predators release numerous substances contained in very different areas of the prey body.

Competing Interests: No competing interests were disclosed. 
The benefits of publishing with F1000Research:

- Your article is published within days, with no editorial bias

- You can publish traditional articles, null/negative results, case reports, data notes and more

- The peer review process is transparent and collaborative

- Your article is indexed in PubMed after passing peer review

- Dedicated customer support at every stage

For pre-submission enquiries, contact research@f1000.com 